DOI https://doi.org/10.30525/978-9934-588-92-1-5

\title{
THE POLITICAL AND LEGAL LESSONS OF THE FRENCH REVOLUTION OF 1789-1799
}

\author{
Dzholos S. V. \\ PhD (Law), Associate Professor, \\ Associate Professor at the Chair of State and Legal Disciplines \\ Bohdan Khmelnytsky National University of Cherkasy \\ Cherkasy, Ukraine
}

According to the socialistic doctrine, in the Soviet times the French Revolution of 1789-1799 was considered to be a great example of the eternal fight of the poor labour people against the cruel exploiters. The masses of the people perceive the revolutionaries as "their own", men of the people, heroes and patriots who selflessly fight against tyranny and social injustice. According to the liberal doctrine, the French Revolution of 1789-1799 is a "giant leap for mankind" on its way to democracy, freedom, equality and human rights. At the same time, several millions of its victims are "insignificant trifle" on the way to the great aim. In our time, the revolutions are actively inculcated in the third world countries, to destroy them finally. So, the troubles and horrors of the French Revolution, as the example of the destructive potential of any riot and uprising, should be rethought to avoid these mistakes in future and to protect the society from the self-liquidation.

Any revolution, including the French, is a crime against the political system, state and all its population. When the common sense, legality, law and order are sacrificed to the revolutionary practicability, we should ask many questions. Was there no usurpation of power when, on the $17^{\text {th }}$ of June 1789, the delegates of the Estates General from the Third Estate proclaimed themselves the National Assembly? Wasn't legitimate the attempt of Louis XVI to disperse by force a band of impostors? Are the acts of the National Constituent Assembly, the National Legislative Assembly and the National Convention legal, if they came to power illegally? Was it not a crime to storm and destroy the Bastille (a state institution, an architectural monument of the XIV century), to assassinate its governor marquis de Launay and soldiers of garrison and to release illegally 7 prisoners on the $14^{\text {th }}$ of July 1789 ? Was Louis XVI a tyrant if there were only seven prisoners in the main state political prison, the Bastille? Weren't the crimes the executions of the king and queen in 1793? Were the Royalists of the Vendée and of the 13 Vendémiaire the rebels, if they wanted to restore the illegally overthrown 
monarchy? Are justified the millions of victims of the Terror, famine, epidemics, Revolutionary and Napoleonic Wars?

In a period of the Reign of (Jacobin) Terror in 1793-1794 about 17,000 person had been executed in France under form of law. The number of people, who were massacred without the pretence of a trial, can never be accurately known, but must be reckoned far greater. Hundreds of thousands people were arrested and many of them died in filthy jails. About 150,000 became émigrés [1, p. 165]. So, Plato is right that democracy leads to tyranny [2, p. 262]. At the same time, only $9 \%$ of victims were the real enemies of the revolution [3, p. 311]. The total number of victims of the French Revolution is unknown. About 200,000 people (the royalists and the republicans) died only in the War in the Vendée of 1793-1796 [4; 5, p. 504]. Also, hundreds of thousands people died of famine, epidemics and the French Revolutionary Wars. According to P. Sorokin, the total casualties of the French Revolution and Revolutionary Wars in 1789-1801 are 1,400,000 people [6].

It is well known that on the $27^{\text {th }}$ of July 1794 the Coup d'état of 9 Thermidor led to the fall of Maximilien Robespierre and stopped the Reign of (Jacobin) Terror. In the period of the Directory (1795-1799) the corruption, bank speculation, financial fraud and misery of people were very common in France [3, p. 312]. After that on the $9^{\text {th }}$ of November 1799 the Coup of 18 Brumaire brought Napoleon to power. The new Constitution of France of 1799 (the Constitution of the Year VIII) separated the legislative power among 4 (!) different organs - the Council of State, the Tribunat, the Legislative Corpus, the Conservative Senate - and paralyzed it. The Dictatorship of Napoleon was established [3, p. 313]. This example shows us that excessive separation of power leads to its inefficiency and collapse. So, for example, the creation of many new anti-corruption organs in modern Ukraine (the National Agency for Prevention of Corruption, the National Anti-Corruption Bureau of Ukraine, the State Bureau of Investigation, the Special Anti-Corruption Public Prosecutor's Office, the High AntiCorruption Court of Ukraine) will have the same effect: as long as new and old bodies fight for power, corruption will blossom.

Eight constitutions were adopted in the period of the French Revolution and the Napoleonic Wars (the constitutions of 1791, 1793, 1795, 1799, 1802, 1804, the charters of 1814 and 1815). So, J. Bodin is right that in a democracy there are many laws, but the common cause is in decline [7]. So, the adoption of many new laws reduces the effectiveness of the legal system, creates conflicts and shows the chaos.

Austria, Prussia, Russia, Britain and other states reacted negatively to the French Revolution, so the French Revolutionary Wars took place in 17921793 and the Napoleonic Wars - in 1800-1815. So, all of Europe did not know peace from 1789 to 1815 . The estimates of the French casualties in the 
Napoleonic Wars of 1800-1815 range from 500,000 to 3,000,000 [8, p. 13]. Geoffrey Ellis writes that France lost as killed in action, died of wounds and camp disease 1,400,000 people during the period 1792-1815, including 916,000 (or 65\%) under the Empire. Total war dead among of all European armies equals 3,000,000 during the Revolutionary and Napoleonic Era (65\% or 1,950,000 under the Empire). Also, 1 million of civilians perished [9]. So, "Liberté, égalité, fraternité, brought to the Europe by the French Revolution and its consequences, cost at least 4,000,000 lives.

It is well known that Napoleon proclaimed himself emperor in 1804, so, in fact, the monarchy was restored in 10 years before the Bourbon Restoration. So, we have all grounds to say that the illusive achievements of the French Revolution were poor in comparison to the real losses. P. Goubert writes that many remnants of the Ancien Régime survived after the revolution and were developed after the Bourbon Restoration in 1814 [10, p. 245-247]. R. Palmer writes that in the half of the century after 1789 the conditions of life in France would be the same as in the case if there was no any revolution [11, p. 253-254].

After the French Revolution and the Napoleonic Wars the political turmoil shook France throughout all the XIX century (the Bourbon Restoration in 1814, the Hundred Days War of 1815, the July Revolution of 1830 , the Revolution of 1848 , the coup d'état of 1851 and the establishment of the Second Empire of Napoleon III, the Franco-Prussian War of 18701871, the Paris Commune of 1871, etc.).

So, the only one good consequence of the French Revolution was the creation of the doctrine of conservatism. It was formed as the reaction on the events (horrors) of the French Revolution of 1789-1799. Its main ideas were written in a famous book of Edmund Burke "Reflections on the Revolution in France" (1790). As Edmund Burke put it, we have to see ourselves as involved in "a partnership not only between those who are living, but between those who are dead and those who are to be born" [12]. So, the main ideas of conservatism are preservation of historical traditions; counteracting innovations and transformations in society, because they may destroy it; coordination of selfish interests of a person with the needs of society; inadmissibility of social upheavals, possibility of only a gradual changes; a great role of the state and traditional values in the life of society, etc. [13].

So, we came to the conclusion that: 1) the history shows that any revolution (the Dutch, the English, the French, the Russian, etc.) is a crime against the state, which leads to the civil war, foreign military intervention, terror, tyranny, devastation, famine, epidemic, losses of the territory, etc.; 2) the revolution is an example of political adventurism (a risky dubious action designed for accidental success), which usually ends in failure and terrible consequences; therefore, any revolution is inadmissible in principle; 3 ) revolution (riot, uprising) is a favorite 
way of gaining power by opposition political elites, who care about the public welfare even less than the regime they overthrew; at the same time, the people are the object of manipulation of a band of scoundrels, and thoughtless "cannon fodder" that dies and becomes poorer "in the name of revolution"; 4) the conservative doctrine is an important basis of the stability and prosperity of the society, because it prevents the horrors of revolutionary upheavals and the state self-destruction, etc.

\section{References:}

1. Holland, Arthur William. French Revolution, The // The Encyclopaedia Britannica: a Dictionary of Arts, Sciences, Literature and General Information. Eleventh edition. Volume XI: Franciscans to Gibson. New York: Encyclopaedia Britannica, Inc., 1910-1911. P. 154-171.

2. The Republic of Plato. An Ideal Commonwealth. Translated by Benjamin Jowett, M.A. With a special introduction of William Cranston Lawton. Revised edition. London - New York: The Colonial Press, 1901.

3. Хома Н.М. Історія держави та права зарубіжних країн. Навчальний посібник для студентів вищих закладів освіти. 3-тє видання, стереотипне. Львів: Новий Світ-2000, 2012. 480 с.

4. Hussenet, Jacques. "Détruisez la Vendée!" Regards croisés sur les victimes et destructions de la guerre de Vendée. La Roche-sur-Yon: Centre vendéen de recherches historiques, 2007.

5. Martin, Jean-Clément (dir.). Dictionnaire de la Contre-Révolution. Perrin, 2011.

6. Sorokin, Pitirim. The Sociology of Revolution. New York: Howard Fertig, 1967. 428 p.

7. Bodin, Jean. Six Books of the Commonwealth. Translated by M.J. Tooley. Oxford: Basil Blackwell, 1955. 212 p.

8. Каминский Л.С., Новосельский С.А. Потери в прошлых войнах (1756-1918): справочная книга. Москва: Государственное издательство медицинской литературы, 1947. 212 с.

9. Ellis, Geoffrey. The Napoleonic Empire. The second edition. Basingstoke: Palgrave Macmillan, 2003. 184 p.

10. Goubert, Pierre. L'Ancien Regime. Paris, 1973.

11. Palmer, Robert Roswell. The World of the French Revolution. New York: Harper \& Row, 1971. 282 p.

12. Burke, Edmund. Reflections on the Revolution in France. Indianapolis, IN: Liberty Fund, 1999.

13. Alexander, James. The Major Ideologies of Liberalism, Socialism and Conservatism // Political Studies. December 2015. Volume 63, Issue 5. Pages 980-994. https://doi.org/10.1111/1467-9248.12136. 